\title{
Likelihood representation in the owl's sound localization system
}

\author{
Fanny Cazettes $^{1 *}$, Brian J Fischer ${ }^{2}$, José L Peña ${ }^{1}$ \\ From Twenty Second Annual Computational Neuroscience Meeting: CNS*2013 \\ Paris, France. 13-18 July 2013
}

The tug of war between expectation and evidence is an intricate problem in perceptual judgments. The Bayesian framework provides a probabilistic solution to this problem. It describes how sensory information, represented by a likelihood function, is combined with previous knowledge of the world, known as the prior distribution, to generate optimal behavioral outputs. Thus, the shape of both the likelihood and the prior determine whether neural representations obey optimal coding. Yet, how the brain represents likelihood functions is unknown. Here, we address this question in the auditory system of barn owls, which displays a map of space in the external nucleus of the inferior colliculus (ICx) [1,2]. Due to their non-ambiguous tuning to interaural time differences (ITD), a critical spatial auditory cue, ICx neurons are selective to horizontal direction $[3,4]$. This selectivity arises from the convergence of frequency channels that originate in lower-brainstem ITD-detector cells narrowly tuned to frequency [5-7]. If ICx neurons implement Bayesian inference, spatial tuning in ICx should conform to the relationship between sound direction and ITD specified by the likelihood. The proposed likelihood model predicts that the widths of the tuning curves should increase with eccentricity [8]. Because the width of ITD tuning curves is determined by the preferred frequency of the cells [9], we hypothesize that non-uniform frequency convergence is involved in non-uniform spatial tuning. Yet, the pattern of frequency convergence across space has never been linked to the spatial tuning widths. Interestingly, theory [8] predicts that ITD tuning across frequency should also be determined by the filtering properties of the head.

\footnotetext{
* Correspondence: fanny.cazettes@phd.einstein.yu.edu

'Department of Neuroscience, Albert Einstein College of Medicine, Bronx, New York, 10461, USA

Full list of author information is available at the end of the article
}

We investigate how frequency convergence governs ITD integration across frequency to understand the physiological representation of likelihood. We examine the tuning properties of midbrain neurons using in vivo extracellular recordings. The preferred ITDs and ITD tuning curve widths were measured at fine resolution in ICx. Consistent with our hypothesis, we found that the non-uniform ITD tuning predicted by the likelihood model is not present at stages in the ITD pathway where neurons do not integrate across frequency. We have also examined the relationship between frequency tuning and ITD tuning. Importantly, we found that the distribution of preferred frequency in ICx also depends on ITD tuning. We are currently testing if the representation of likelihood relies on the filtering properties of the head by assessing whether ITD tuning varies across frequency and space.

The experimental results are combined to model how the network represents the statistical dependence of ITD on sound direction. The input signals to the ears are first filtered with a gammatone filter. ITD curves are then extracted from the output of the filterbank using a cross-correlation operation [7]. ITD-curves are merged with different weights estimated from the data and a linear-nonlinear Poisson model is used to describe the responses in ICx. With our model we can parse out the importance of each mechanism in the representation of likelihood.

\section{Acknowledgements}

Work supported by the US National Institutes of Health, NIDCD Grant R01 DC 12949, as part of the NSF/NIH Collaborative Research in Computational Neuroscience Program.

\section{Author details}

'Department of Neuroscience, Albert Einstein College of Medicine, Bronx, New York, 10461, USA. 'Department of Mathematics, Seattle University, Seattle, Washington, 98122, USA.
C Biomed Central

() 2013 Cazettes et al; licensee BioMed Central Ltd. This is an Open Access article distributed under the terms of the Creative Commons Attribution License (http://creativecommons.org/licenses/by/2.0), which permits unrestricted use, distribution, and reproduction in any medium, provided the original work is properly cited. 


\section{References}

1. Knudsen El, Konishi MA: Neural map of auditory space in the owl. Science 1978, 200(4343):795-797.

2. Knudsen El: Auditory and visual maps of space in the optic tectum of the owl. J Neurosci 1982, 2:1177-1194.

3. Takahashi T, Konishi M: Selectivity for interaural time difference in the owl's midbrain. J Neurosci 1986, 6(3):3413-3422.

4. Moiseff A, Konishi M: Neuronal and behavioral sensitivity to binaural time differences in the owl. J Neurosci 1981, 1(1):40-48.

5. Carr CE, Konishi M: A circuit for detection of interaural time differences in the brain stem of the barn owl. J Neurosci 1990, 10(10):3227-3246.

6. Mazer JA: How the owl resolves auditory coding ambiguity. Proc Natl Acad Sci 1998, 95:10932-10937.

7. Fischer BJ, Christianson GB, Pena JL: Cross-correlation in the auditory coincidence detectors of owls. The J Neurosci 2008, 28(32):8107-8115.

8. Fischer BJ, Pena JL: Owl's behavior and neural representation predicted by Bayesian inference. Nature Neurosci 2011, 14(8):1061-1066.

9. Wagner H, Mazer JA, von Campenhausen M: Response properties of neurons in the core of the central nucleus of the inferior colliculus of the barn owl. Eur J Neurosci 2002, 15(8):1343-1352.

doi:10.1186/1471-2202-14-S1-P128

Cite this article as: Cazettes et al: Likelihood representation in the owl's sound localization system. BMC Neuroscience 2013 14(Suppl 1):P128.

\section{Submit your next manuscript to BioMed Central} and take full advantage of:

- Convenient online submission

- Thorough peer review

- No space constraints or color figure charges

- Immediate publication on acceptance

- Inclusion in PubMed, CAS, Scopus and Google Scholar

- Research which is freely available for redistribution

Submit your manuscript at www.biomedcentral.com/submit
C Biomed Central 